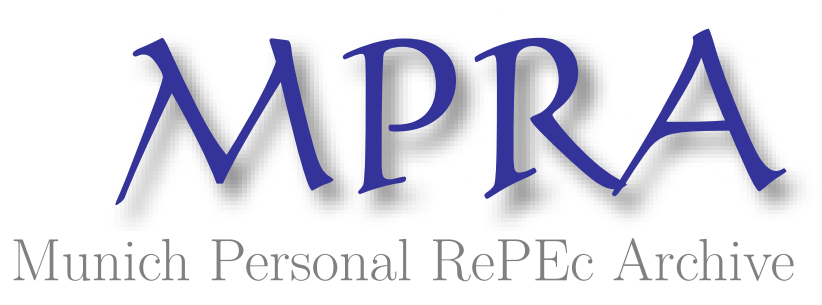

\title{
History of Economics or a Selected History of Economics?
}

Palma, Nuno

Northwestern University

10 September 2007

Online at https://mpra.ub.uni-muenchen.de/5111/

MPRA Paper No. 5111, posted 02 Oct 2007 UTC 


\title{
History of Economics or a Selected History of Economics?*
}

Nuno Pedro G. Palma ${ }^{\perp}$

Word Count: 74 (abstract), 4,887 (main text), 774 (endnotes).

This version: Final, submitted for editorial proofs at JHET, September 2007.

\begin{abstract}
While research on the history of economics can be important to modern economics, the work of historians of economics is more often than reasonable associated with either non-contemporary or heterodox issues. I provide quantitative evidence of this, by analyzing the publications in the three main history of economics journals over the last fourteen years (1993-2006). This trend must change if the work of historians of economics is to be taken seriously by mainstream economists.
\end{abstract}

\section{INTRODUCTION}

When asked about the importance of research on the history of economics for modern economics, most mainstream economists will argue that it is not important at all. Things written more than ten or fifteen years ago are generally deemed either irrelevant or out-

\footnotetext{
*Without the encouragement of José Luís Cardoso this paper would not have been written. A previous version was presented at the "Future of the history of economics: young scholar's perspective" symposium at the $10^{\text {th }}$ (2006) ESHET conference in Porto, Portugal. I thank all participants, in particular Roger Backhouse, Axel Leijonhufvud, and Heinz Kurz. Previous versions benefited from the comments of two anonymous referees, Erik Angner, José Luís Cardoso, Luís Aguiar-Conraria, Ivan Moscati, Paulo Rosário, Eric Schliesser, and Paola Tubaro. Needless to say, I retain full responsibility for this article.

${ }^{\perp}$ Department of Economics, Northwestern University: 2001 Sheridan Road, Evanston, IL 60208, USA. E-mail: nuno.palma@northwestern.edu
} 
dated in the sense that if they are useful then they are incorporated into more recent work. Thus the image of cumulative science is pervasive in economics. My purpose with the present paper is twofold: first, to argue that research on the history of economics can be important to modern economics and second, to criticise the way this research is usually performed today, as well as suggest a new way forward.

Today, research on the history of economics either does not consider modern mainstream issues, including their modern history, or when it does, it is typically written in opposition to them. For this reason, today's history of economics can be characterized as a selected history of economics, in a double sense. I argue that it would be important for this to change, and that this change would enhance the often lacking communication between historians of economics and mainstream economists ${ }^{1}$.

Section 2 is a discussion about the potential importance of history of economics to research in economics, and provides a set of (normative) principles for historians. Section 3 is a (positive) analysis of the present practice of research on the history of economics. The evidence shows that historians of economics devote little time studying contemporary mainstream economics, and that the ones who do are generally hostile to it. Section 4 presents some reasons for this neglect, and the conclusion, section 5, will consider some consequences of the previous evidence and discussion, as well as suggest a different course for the history of economics.

\section{WHY HISTORY?}

The claim of the history of economics to be a part of economics is under attack ${ }^{2}$. While the history of economics is sometimes taught at the undergraduate level, especially in US liberal arts colleges, in Europe and Japan, it has virtually disappeared from graduate 
curricula, especially at the top-ranked institutions, and historians of economics find it hard to be hired as faculty in prominent departments.

One explanation for the dismissal of the history of economics is that this is a consequence of the increasingly scientific nature of economics. Natural sciences tend to build a systematic reconstruction of their past, and largely ignore whatever is not included in the emerging synthesis. If one looks at the average paper in a mainstream economics journal there will seldom be a citation with more than one decade. The implicit view seems to be that if some idea is worthy, it will become either integrated into more recent research or considered "common knowledge", thus making a citation unnecessary. From this perspective, the history of economics can be ignored by economists, and belongs to a different department such as philosophy or history, in a similar fashion as it happens with the history of physics.

There are however significant reasons to think that the history of economics should not only survive but also flourish as a field of study within economics, and why in some cases it can indeed influence the frontier. The most obvious is that it is important not to re-invent the wheel. Historians of economics should be able to systematize the past making an informed judgement on what constitutes the relevant part of past knowledge, even if this is not part of the current focus of frontier research. As argued in Kenneth Boulding’s (1971) essay “After Samuelson, Who Needs Adam Smith?”, it is possible I should add plausible - that there exist important arguments and insights from past authors that are not fully incorporated in the present day synthesis.

From here it can be argued that research on the history of economics has the potential to bring new ideas to contemporary economics, but of course its real role is to prevent good old ideas from being lost. While independent rediscoveries in science are probably inevitable to some degree, and are certainty not infrequent in economics, their optimal 
amount of rediscoveries is not zero. Since resources are limited, not all wheels can be saved, or should, thus the historian of economics has to bear in mind his role as a selector about what to preserve for the future as a legitimate and important contribution to economics. I agree with Axel Leijonhufvud [e.g. (2006)] that this is not limited to the highway to the present ${ }^{3}$. If scientific progress is seen as a decision tree, those roads that were not taken in the past provide an open window to new developments, in particular if the previous mainstream line of research, which is the result of a particular path, has entered diminishing returns. Thus a Whig history that ignores past nodes and decisions is incomplete, less helpful, and can forget important ideas. I like to think of this as the possibility of a "back to the future" argument ${ }^{4}$, but I nonetheless emphasize that, on the one hand, backtracking has to be made with great care and on the other, no backtracking can be made without profound knowledge about the current state, i.e. the present.

A related reason is that in this age of increasing specialization, historians of economics should be able to look at the present in historical perspective. For some economists, history of economics is just about surveying the literature of the past, and surveys can be done better by specialists in the relevant field. Yet, surveys from nonhistorians are usually short-sighted from a historical perspective, and historians' work is likely to be more historically rigorous. Frontier research consists of a huge flow of information in which fashion plays an enormous role. Analyzing recent research in historical perspective helps recognizing what the really important questions are, and provides a way for historians to write about relatively recent developments in a way that their work is not simply a literature review, but something different, of a much less narrow and more profound nature. Furthermore, due to the appeal to traditional "standing on the shoulders" authority as a rhetorical strategy, the prevention of interpretations which are historical travesties can be important. Research in intellectual 
history has the authority to set the record straight, but this should not be an end in itself. A side note is that the previous discussion may no less apply to other fields of scientific inquiry, including physics, but there is the possibility that this issue is more serious for the social sciences, for reasons idiosyncratic to them.

Historians of economics often do small "m" methodology, which has the potential to influence mainstream economics. For reasons I will make my best effort to make clear, there are not plenty of examples of this today, but an earlier concrete example is Lionel Robbins' early methodological essay. An Essay on the Nature and Significance of Economic Science [Robbins (1932)] redefined the scope of economics and was a defence of abstract theorizing as well as a critique of Marshallian intuitionism. In the essay, Robbins attacks the value judgments on which measurable utility rested. His program was soon after taken up by Hicks and Allen, thus influencing mainstream economics in a significant way [see Backhouse (2003, pp.311-12)] $]^{5}$. Outside economics, Thomas Kuhn is a wonderful example of how the interaction between the history and methodology of science can be naturally fruitful.

Finally, all positive results in economics, theoretical and empirical, are based on a choice of assumptions, and a crucial part of methodological work can be to identify them. Whatever the research methodology, it requires a choice of issues to disregard and others to emphasise. The historian-methodologist has here an important role in pointing out exactly which results depend on which assumptions (some of which can have been chosen normatively, thus creating a normative basis for so-called positive results). As an example, think again of Robbins' 1932 Essay: an important part of it was a serious analysis and critique of several assumptions behind the results of economic theory. The importance of looking at the foundational assumptions of a research program cannot be overemphasized. Writes Leijonhufvud (2006, p.16): 
If you cannot think outside the box, how do you know you're in the right box? (...) If successive decisions have narrowed the options to the point where the box gets claustrophobic, back tracking reopens lost vistas.

I have heard the argument that studying the history of economics can "trap" someone in old ideas, preventing a scholar to develop new ideas. There may be some degree of truth in this - but there is no reason why this should apply more to the history of economics than to any other field: it is easy, for example, to think of someone being trapped in the literature of public finance; or in the assumptions of perfect competition as well. Researching intellectual history does not have to be at the expense of creating it.

\section{THE STATE OF PRESENT RESEARCH ON THE HISTORY OF ECONOMICS}

The main purpose of the present essay is to argue that more research on the history of economics should be done along the lines of contemporary mainstream economics. This is not to despise the work on Austrian, Marxist, Post-Keynesian, or any other heterodox material, nor the work about the not-so-recent past. But just as all that work is important, current mainstream work is important too. Even if we adapt the "dead for thirty years" criterion, which is on itself subject to critique, more research should be done about the work of, say, Nobel laureates, not to mention John Bates Clark or Yrjö Jahnsson medallists. This work did not need to be passive and certainly not Whiggish in fact it could critically access the researcher's work, especially in historical perspective, and make fundamental suggestions for future winners. 
What I say does not mean that historians should a-critically accept the Nobel history. It is legitimate to offer an informed judgment about someone who should have received the prize but did not, for instance. But more discussion is clearly needed, about its laureates, possible past candidates, and what is perhaps more important, possible future winners. Historians of economics are in a unique potential position to take a lead in this discussion, yet they are seldom part of it at all, often because they are discussing the life of some obscure XIXth century figure. That is their role too, surely, but no less than looking at the present in historical perspective. Should a Nobel Prize really be something unexpected? I am writing here and now, London, July 2007, and I say Paul Romer is going to win the Nobel Prize in economics. Personally, I think it will be well deserved, and I could develop why. But it could easily be the other way around. The point is, when someone wins, how often is there a historical account of that person's work available - even if included in a broader historical discussion? Should the laureate win first and only after the first draft of his intellectual history be written, if at all? When someone wins it is always the non-historian colleagues that write reviews for journals. I see a world where historians of economics engage a realistically impartial discussion about the merits of different candidates, in particular in historical perspective, but we are certainly very far from that world today. In fact, a historical account about the intellectual history concerning many of the existing laureates since 1969 does not even exist.

When the editors of The European Journal of the History of Economic Thought asked several Nobel economists about the most important contributions of twentieth century economics, most answered things like game theory, macroeconomics, and the development of general equilibrium theory. Arrow (2001), for example, answered game theory and imperfect competition, the economics of information, general equilibrium 
theory, national income accounting, and the emergence of economic growth and development as a field of study. Almost everyone recognizes these are important areas of research; however it is difficult to find papers on the history of economics about these themes, at least not their early history.

The following table shows some statistics about the articles that have been published in the three main journals of the field from 1993 to 2006 . The sections that follow do not wish to represent any special division of periods by schools of thought, but only to provide a mere temporal division for the sake of analysis.

\begin{tabular}{|c|c|c|c|c|c|c|c|c|}
\hline & \multicolumn{2}{|c|}{$\begin{array}{l}\text { History of Political } \\
\text { Economy }\end{array}$} & \multicolumn{2}{|c|}{$\begin{array}{c}\text { J. of the History of Ec. } \\
\text { Thought }\end{array}$} & \multicolumn{2}{|c|}{$\begin{array}{c}\text { E. J. of the History of Ec. } \\
\text { Thought }\end{array}$} & \multicolumn{2}{|c|}{ Total } \\
\hline & Articles & $\begin{array}{l}\text { Rel. nr. of } \\
\text { articles }\end{array}$ & Articles & $\begin{array}{l}\text { Rel. nr. of } \\
\text { articles }\end{array}$ & Articles & $\begin{array}{l}\text { Rel. nr. of } \\
\text { articles }\end{array}$ & Articles & $\begin{array}{l}\text { Rel. nr. of } \\
\text { articles }\end{array}$ \\
\hline Pre-Classical & 70 & $10.9 \%$ & 16 & $5.2 \%$ & 37 & $12.8 \%$ & 123 & $10.0 \%$ \\
\hline Adam Smith & 38 & $5.9 \%$ & 17 & $5.6 \%$ & 22 & $7.6 \%$ & 77 & $6.2 \%$ \\
\hline $1770-1870$ & 77 & $12.0 \%$ & 37 & $12.1 \%$ & 47 & $16.3 \%$ & 161 & $13.0 \%$ \\
\hline $1870-1900$ & 37 & $5.8 \%$ & 36 & $11.8 \%$ & 31 & $10.8 \%$ & 104 & $8.4 \%$ \\
\hline $1900-1945$ & 114 & $17.8 \%$ & 57 & $18.6 \%$ & 43 & $14.9 \%$ & 214 & $17.3 \%$ \\
\hline 1945-today & 37 & $5.8 \%$ & 19 & $6.2 \%$ & 17 & $5.9 \%$ & 73 & $5.9 \%$ \\
\hline Cross-Section & 61 & $9.5 \%$ & 42 & $13.7 \%$ & 39 & $13.5 \%$ & 142 & $11.5 \%$ \\
\hline Commentaries/Replies & 64 & $10.0 \%$ & 28 & $9.2 \%$ & 11 & $3.8 \%$ & 103 & $8.3 \%$ \\
\hline Other/Methodology & 144 & $22.4 \%$ & 54 & $17.6 \%$ & 41 & $14.2 \%$ & 239 & $19.3 \%$ \\
\hline Total & 642 & $100.0 \%$ & 306 & $100.0 \%$ & 288 & $100 \%$ & 1236 & $100.0 \%$ \\
\hline
\end{tabular}

Table 1. Articles in HET Journals ${ }^{6}$

When browsing these journals, I found it intriguing how many articles exist on a series of pre-classical authors, notably Quesnay, on Smith and Malthus, and even a series of early twentieth century heterodox authors, and above all, how little on contemporary (and late) mainstream authors from the twentieth century. As I said 
before, it is important to pay attention to heterodox theory, as well as studying the notso-recent past. However, much of the importance of this relies on the impartial comparison with contemporary mainstream theory, if this kind of research is done. But in fact, the relative attention given by historians of economics to contemporary, especially mainstream, economic theory is simply too small. If the $5,9 \%$ dedicated to 1945-today does seem a small amount, this only gets worse when we take the following into consideration: 1) some of these articles are on heterodox authors, 2) there are almost no papers at all concerning the period after 1970 and 3) the small amount of work that is indeed about contemporary mainstream theory, is often in opposition to it. Let's take for example an exception to the first two premises: Sent's work on the history of rational expectations (Sent 1999) - it is not an exception to the third. Many more cases exist; Louçã (2004) is a relatively recent related example, and one of the few major historical works that do exist about New Classical economics is no different, as its subtitle “A Sceptical Inquiry” openly indicates (Hoover 1988). Why doesn't there exist at least one historical article in defence of New Classical economics, or neutral, for each attacking it? If it sounds shocking to you that history can sometimes defend a position and thus that there could be an article defending New Classical economics, consider first how many there are attacking that research agenda (Sent's PhD dissertation, entitled "Resisting Sargent", won the Joseph Dorfman award). Why is the opposite any more acceptable? There are indeed few exceptions to three premises taken together. Some good examples do exist, mainly in the "cross-section" section, but they remain a very small portion of the cake. Lionel Robbins wrote in the first page of the above mentioned essay (Robbins 1932, p.1): "The efforts of economists during the last hundred and fifty years have resulted in a body of generalizations whose substantial accuracy and importance are open to question only by the ignorant or the perverse". I wonder how 
many historians of economics would undersign this today, but my guess is not optimistic.

The evidence is not limited to publication in journals. The numbers above do not cover books, but the picture in books, although more difficult to track and evaluate ${ }^{7}$, does not seem in general different - think again about Hoover (1988). When I presented an early version of this paper at the 2006 ESHET conference, I remarked that there were almost no papers about contemporary mainstream economics in the program of the conference, and that those that were indeed, had a heterodox perspective that was readily evident from the paper title. I was not the only one to notice this. In his Blanqui lecture at the same conference [part of what would become Weintraub (2007)], E. Roy Weintraub (2006, p.11) said:

"A quick examination of the program of these meetings in Porto, or any History of Economics Society meeting, will locate two primary intellectual themes: work on 'very old' economics (...) and critical work on issues treated in mainstream economics today"

What the evidence thus shows is that analyzing recent mainstream economics from a non dissent perspective is something historians of economics rarely do. There are counterexamples out there, but my statement is about the distribution. The existence of outliers should not compromise the general conclusion about the population. Thus I am not saying no single work exists about modern economics from a non-critical perspective. What I say is, present research in HET is "selected" - which is a better word than biased because it does not suggest that a single "correct" direction exists i.e. there is much less non-de-legitimizing historical work about contemporary mainstream issues than would be naturally expected, and this strongly contributes to historians of economics to be de-legitimized themselves by economists. 
Furthermore, historians of economics seem to be willing to move towards the future much slower than they should be. Also, articles tend to focus a lot more on one or a small number of individuals than on schools of thought and comparisons, either crosssection or intertemporal, between these, as well as on economic theory, despite the fact that much of modern research is primarily empirical.

\section{THE NEGLECT OF CONTEMPORARY HISTORY}

The last section concluded that historians of economics devote little attention to contemporary mainstream economics, and that when they do, it is almost always in opposition to it. So this raises the question: why so? Why is it that there exists in the leading journals more research articles about the single figure of Adam Smith (6,2\%) than about all of the history of Post-World War II economics taken together (5,9\%)? Please take the question seriously as the latter period lasts for 62 years, and those in all history where more resources have been allocated to economics research.

To sketch an answer to this problem, I will divide the question in two parts: First, why do historians of economics devote little attention to contemporary mainstream theory?, and second, why is it that when they do it is usually in dissent? The answers are clearly related, but nevertheless deserve separate attention.

The fact that journals do not publish enough articles about the history of modern mainstream economics is unlikely to be a deliberate editorial policy. The answer certainly involves something which can be called the "fog effect": if a given phenomenon is close to someone in time, it is harder to analyse historically. It is sometimes argued that contemporary theory is difficult to analyse because a historical reconstruction would require access to manuscripts that are not currently available. 
Even if this is true in the short run, it does not however rule out the role of history of analysis. History of analysis has the benefit that it does not require the analysis of manuscripts, and its appearance can be complementary to the eventual later appearance of historical reconstructions when the necessary archival material becomes available. Also, historians of natural science, for instance physics, do a lot of oral history, through interviews with leading physicists, which historians of economics could do as well, though they usually do not ${ }^{8}$.

The year 2007 marks two anniversaries: The 71st of John M. Keynes' book 1936 The General Theory of Employment, Interest and Money and the 35th of Robert Lucas' 1972 paper "Expectations and the Neutrality of Money". Whatever are the reasons, the truth is that at the 35th anniversary of the General Theory of Employment, Interest and Money in 1971, there was a lot more historical work about Keynesianism than there is today about New Classical economics at the 35th anniversary of Lucas' seminal work. Yet, any contemporary mainstream macroeconomist will agree that the appearance of rational expectations as applied to macroeconomics has had at least the same revolutionary effect on the field as the Keynesian "revolution".

A leading explanatory candidate for this problem is that the mathematical apparatus of modern mainstream economics works as a barrier to entry in the study of contemporary theory that do not exist in studying earlier periods. A strategically obscure oeuvre such as The General Theory, especially being almost non-mathematical by modern standards, and one whose author has died, may generate more interpretative controversy than a more straightforward mathematical text ${ }^{9}$. Yet, none of these cannot serve as excuses for historians, as the formalization of economics is not likely to go away in any foreseeable future, and historians will eventually have to analyse modern economics or they will be stuck forever in the distant past. Historians seem to show 
resistance to the use of mathematics in general, not only by making frequent attacks on the mainstream on the grounds of mathematical narrowness, but even in their own historical work, where they sometimes could use mathematical methods (including stylometrics), but usually do not.

The remaining unanswered question is: why are so many of the few articles that do exist about contemporary mainstream work written in opposition to it? This question certainly has to do with the problems discussed by Lodewijks (2003). It turns out that the history of economics has been used as a refuge by a large number of heterodox economists due to the rapid decline in popularity of their own approach. The history of economics is then used as an instrument for a disguised critique of mainstream economics from a heterodox perspective which in fact carries underneath a well defined agenda. The history of economics is indeed a "heaven for heterodoxy" (Blaug 2001). This is not acceptable if it biases the integrity of the historical analysis. Also, if it is performed by the majority of the historians of economics that work on contemporary issues, as it seems to be the case, it certainly contributes to the mainstream economists' dismissal of historians of economics. This very same point was strongly emphasized by Weintraub in his above mentioned Blanqui Lecture (Weintraub 2006, pp.12-13, original emphasis):

"The economic science wars are associated with economists' correct beliefs that heterodox economics is hostile to mainstream economic science. And as a consequence, the history of economics, as and to the extent that it is associated with heterodoxy, is considered to be hostile to mainstream economics $(\ldots)[\mathrm{H}]$ istorians and methodologists of economics are not seen as any "threat" to mainstream economists. Indeed they are invisible to economists. The science war ended years ago in a science peace in economics. The argument, the war, is over except that 
some of the losers still say 'you need to deal with us, why won't you pay attention to us?' The economic science war is over, and we historians of economics have lost".

It thus seems that I am not the only one to believe that historians of economics are the first to be hurt by their general dismissal of mainstream economics and association with heterodoxy. Yet, I disagree with the position of Weintraub and others that the

association of the history of economics with science-studies is necessary or recommended for the field's survival. Actually, "breaking away" (as Schabas 1992 recommended and others followed) would mean that historians of economics would in fact cease to be economists, at least from the mainstream economist's eye, and would definitely have to abandon any hope for influence on them. This brings me to the conclusion of this essay.

\section{CONCLUSION: CHANGING THE HISTORY OF ECONOMICS}

Historians of economics and mainstream economists seem unable to communicate. The former lament that the latter do not pay attention to the intellectual history of their own discipline, and that publications in history of economics journals carry little weight. Mainstream economists often dismiss the history of economics as irrelevant and unnecessary for current research. A healthy co-existence and collaboration can and should exist between historians of economics and mainstream economists. One main reason for the exclusion of historians of economics from mainstream departments is, in my view, practical. The journal rankings that determine the departmental rankings, and consequently their funding, attribute little weight to history of economics journals, as they receive very few citations from the "top" journals. Historians of economics often complain that the editors of mainstream journals are not open to the publication of 
articles on the history of economics, and so they are relegated to specialist journals, which receive fewer citations and attention ${ }^{10}$. Yet, publishing in mainstream journals is not the only way that historians of economics can attract attention. The alternative is to increase the citations of specialist journals in mainstream journals. Even if more history of economics and methodology journals are included in present and future citation indexes (creating a network effect), this would on its own unlikely attract more attention and prestige to intellectual history from the mainstream. For that to occur, it is necessary that historians of economics analyse issues that are of interest to mainstream economists. And do they? In the second part of this essay I have discussed some reasons why the history of economics can be important for modern research in economics. I stressed the idea that these reasons were normative. Most of the reasons given do not correspond to the work of historians of economics, because, as it was shown in section three, they generally do not analyze contemporary mainstream economics, at least from an impartial position. This means that they are unable to judge in historical perspective the originality of new knowledge, they do not perform relevant small "m" methodological work, and they do not make important methodological considerations about recent results. As a result of all this, their work is of little interest to mainstream economists.

Many historians of economics would not like to leave economics departments and do not like the idea of associating the history of economics with science studies. What I am offering is an alternative, not a formula for a front-door come-back to top economics departments, which simply may not be possible in the foreseeable future, but certainly a solution for increasing the attention given by mainstream economists to historians of economics. A related point is that if historians of economics do not have training as economists, it will be very unlikely that they will be able to keep with current 
developments or have adequate (namely) mathematical training to keep on with current theory [see also Moscati (2008)].

When I say that present research in the history of economics is "selected" I mean that there is much less non de-legitimizing historical work about contemporary mainstream issues than would be reasonably expected, and that this fact strongly contributes for historians of economics to be de-legitimized by mainstream economists. Regarding heterodoxy, there are many cases in the history of economics where a given author or position crossed the boundaries - for instance Milton Friedman's position was considered heterodox in the 1950's and orthodox in the 1970's. Frederick Hayek went the other way around from the early 1930's, where he could be considered part of the neoclassical mainstream, to his later association with a (non-mainstream) specific Austrian interpretation of the neoclassical program. The problem is not per se the presence of heterodox economists among historians of economics, but rather their relative weight, caused by the absence of an equally numerous group of scholars working on mainstream history from a non de-legitimizing perspective. Blaug (2001), Weintraub (2002), and others, noted that the history of economic thought is held in low esteem by mainstream economists. Yet, there is no a priori reason to believe that historians of economics have nothing to teach mainstream economists, or that they will not listen. I have often heard and read historians of economics lament that mainstream economists do not pay attention to the history of economics. The truth is that if they want attention, it is historians of economics that must change their attitudes. To earn the respect of mainstream economists, work in the history of economics should not be intrinsically ideological, cannot eschew formal methods, and must move beyond the frontier of what is usually considered to be the history of economics. The "fog effect", as well as resistance to oral history and mathematics cannot serve as excuses forever. 
Historians of economics can be as much the guardians of the future as the keepers of the past. But for this to happen, intellectual isolation from the mainstream cannot continue. Let's face it: a day will come when Adam Smith will have nothing new to say. But Robert Lucas has.

"Progress, far from consisting in change, depends on retentiveness. When change is absolute there remains no being to improve and no direction is set for possible improvement: and when experience is not retained, as among savages, infancy is perpetual. Those who cannot remember the past are condemned to repeat it."

George Santayana (1980, p.284)

\section{NOTES}

${ }^{1}$ For the sake of concreteness, throughout this article, I refer to the mainstream as what is taught in the "top" departments and found in journals such as American Economic Review, Econometrica, Journal of Political Economy and Review of Economic Studies, as well as the recent history that led to it, where "recent" can be broadly interpreted as "since WWWII".

${ }^{2}$ For recent examples, see Blaug (2001), and Weintraub (2002). For decades now, many presidential addresses of HES and ESHET have been devoted to stressing the "importance" of the field. This very symposium is part of this long-run defensive trend.

${ }^{3}$ Though, and I am getting a bit ahead of the discussion here, the road to the present is certainty something that has to be preserved.

${ }^{4}$ Piero Sraffa comes to my mind a an extreme case of someone whose work would never have been without a massive backtracking, and no matter if one agrees with him or not, it is a fact that this was done with a considerable amount of success. Many less extreme cases have happened. 
${ }^{5}$ It is certainly not irrelevant to note that the contribution of Robbins was part of a broader discussion in his time, and that his work could never have been had he not a profound knowledge of his contemporary theory. This point raises a clue to today's historians and methodologists about the necessity of analysing recent theory. Some may say that this reason only supports the relevance of economic methodology, and not the history of economics. However, as I have already mentioned, these are natural complements as research fields, and often cannot be separated, as the same classification in the JEL codes (B) suggests: "Schools of Thought and Methodology". Robbins, for instance, was an historian of economics as well as an economic methodologist.

${ }^{6}$ Notes about the data: The European Journal of the History of Economic Thought began in 1993, and my counting starts in this year, creating a sample that covers 14 years. A longer counting could not consider this journal, and would decrease the relative weight of recent contributions, which for the present purpose are the more important to analyse. The table includes supplements but excludes book reviews. HOPE supplements are included in the year they were published. Articles on economic history are included in the relevant sections. Section "Adam Smith" includes articles where Smith is mentioned in the title (even if jointly with others) or if the article is directly about Smith's work. It excludes general articles on classical political economy that mention Smith. The section entitled "Cross-Section" includes the articles that concern more than one of the other sections. For example, an article about both Ricardo and Sraffa would appear on this section (and only on this one). The relatively large size of the last section is explained by the inclusion of the papers discussing the history of economics as a discipline.

${ }^{7}$ And this is, historians like it or not, why in general economists attribute less importance to books.

${ }^{8}$ In physics, the interview is normally conducted by professional historians of physics, and the interviews are complemented with independent research. The interviewee's word is not taken for granted and confronted with evidence. In economics, some books interviewing leading economists exist [e.g. the recent Samuelson and Barnett (2007)], but by contrast with physics the interviews are more often than not done by colleagues or former students of the interviewee. This tends to create obvious biases in the oral history that emerges. See Weintraub's "History of Thought Introduction" to the book. 
${ }^{9}$ McCloskey (1998, p.18) writes: "The crafty John Maynard Keynes (...) most influentially in The General Theory of Employment, Interest and Money left many opportunities for readers to run their own internal motion pictures".

${ }^{10}$ The creation of History of Political Economy in 1969 and other specialized journals since was in part a response to the increased difficulty of historians of economics to publish in mainstream journals. Today, it is not completely unusual to see articles on history of economics on these, but written by economists who are generally not historians, and inevitably never cite specialist history of economic thought journals. It is not a coincidence that many of these articles focus on recent issues (e.g. Blanchard 2000). If the history of economics manages to survive as a field, and submissions on recent material start to appear, editors should consider asking authors of papers in mainstream journals to serve as referees. This could be a very important complement to the refereeing by one or more professional historians, and as an added bonus, could motivate the involvement of the more general economists' profession in historians' affairs, something that would benefit both communities.

\section{REFERENCES}

Arrow, K. (2001). The Five Most Significant Developments in Economics of the Twentieth Century. The European Journal of the History of Economic Thought. 8:3, pp. 298-304.

Backhouse, R. (2003). The Stabilization of Price Theory, 1920-1955. In A Companion to the History of Economic Thought, Blackwell, ed. Samuels, Biddle, and Davis.

Blanchard, O. (2000). What Do We Know About Macroeconomics that Fisher and Wicksell Did Not? Quarterly Journal of Economics, November, 115:4, pp. 1375-1409. 
Blaug, M. (2001). No History of Ideas Please, We're Economists. Journal of Economic Perspectives, vol.15:1, pp. 145-164.

Boulding, K. (1971). After Samuelson, Who Needs Adam Smith? History of Political Economy, 3:2, pp. 225-237.

Hoover, K. (1988). The New Classical Macroeconomics: A Sceptical Inquiry. Oxford: Basil Blackwell.

Leijonhufvud, A. (2006). The Uses of the Past. Working Paper, University of Trento.

Lodewijks, J. (2003). Research in the History of Economic Thought as a Vehicle for the Defence and Criticism of Orthodox Economics. In A Companion to the History of Economic Thought Blackwell, ed. Samuels, Biddle, and Davis.

Louçã, F. (2004). Swinging All the Way: The Education of Doctor Lucas and Foes. History of Political Economy, 36:4.

McCloskey, D. (1998). The Rhetoric of Economics. Wisconsin University Press, $2^{\text {nd }}$ Edition.

Moscati, I. (2008). More Economics, Please: We're historians of economics. Journal of the History of Economic Thought, this issue. 
Robbins, L. (1932). An Essay on the Nature and Significance of Economic Science. 1st Edition, London: Macmillan.

Santayana, G. [1980 (originally published 1905)]. The Life of Reason: or, the Phases of Human Progress. Volume 1, Reason in Common Sense. Dover.

Samuelson, P. and W. Barnett (2007). Inside the Economist's Mind: Conversations with Eminent Economists. Blackwell.

Sent, Esther-Mirjam (1999). The Randomness of Rational Expectations: A Perspective on Sargent's Early Incentives. The European Journal of the History of Economic Thought, 6:3, pp. 439-471.

Schabas, M. (1992). Breaking Away: History of Economics as History of Science. History of Political Economy 24: 187-203.

Weintraub, E. (2002). Will Economics Ever Have a Past Again? History of Political Economy, 34, Annual Supplement, pp. 1-14.

Weintraub, E. (2006). Economic Science Wars. Jérome A. Blanqui Lecture. Available at http://www.eshet.net/best/1150129153_blanqui_lecture.pdf

Weintraub, E. (2007). Economic Science Wars. Journal of the History of Economic Thought, 29:3, 267 - 282 